16) A.E. Owen, The Glass Industry 48 [11] 637-42, 58; [12] 695-99 (1967).

17) G.S. Snow, J. Electrochem. Soc. 115 [4] 437-38 (1968).

18) G.L. Sewell, Phys. Rev. 129 [2] 597-608 (1963).

19) H. Fröhlich, "Theory of Dielectrics", Oxford at the Clarendon Press (1958).

フレーリッヒ, 永宮ほか訳, “誘電体論”吉岡書店 (1963).

20) T. Allersma and J.D. Mackenzie, J. Chem. Phys. 47 [4] 1406-09 (1967).

21) H.R. Killias, Phys. Letters 20 [1] 5-6 (1966).

22) J.M. Stevels, "The Electrical Properties of Glass", Handbuch der Physik Vol. 20, p. 351 SpringerVerlag, Berlin (1957).
23) R.J. Charles, J. Appl. Phys. 32 [6] 1115-1126 (1961).

24) A.E. Owen, "Electric Conduction and Dielectric Relaxation in Glass", Progress in Ceramic Science, Vol. 3, p. 78 Pergamon (1963).

25) J.O. Isard, Proc. Instn, Elect. Engrs. 109 B, Sullp., 22, 440-47 (1961).

26) G.W. Anderson, J. Appl. Phys. 39 [3] 1634-38 (1968).

27) A.I. Gubanov, "Quantum Electron Theory of Amorphous Conductor", Consultants Bureau, New York (1965).

28）斎藤省吾, 宗像元介, 第 2 回嘿業基礎討論会講演集 4448 (1964).

(8/5/1968 受付)

\title{
硫酸アルミニウムの熱分解によるアルミナの生成過程*
}

\author{
加藤修三・伊賀武雄・佐野資郎・石井英一 \\ （名古屋工業技術試験所）
}

\section{Formation Process of Alumina by Thermal Decomposition of Aluminum Sulfate}

\author{
By \\ Shūzō KATŌ, Takeo IGA, Shirō SANO and Eiichi ISHII \\ (Government Industrial Research Institute, Nagoya, Nagoya)
}

Thermal decomposition of aluminum sulfate into $\alpha$-alumina was investigated by D.T.A., T.G.A., X-ray analysis and electron microscopic observation.

The results obtained were as follow:

Aluminum sulfate melted in its own water of crystallization when heated, and high viscous solution was obtained. This solution evaporated vigorously above $100^{\circ} \mathrm{C}$. Bubble formation was observed because of difficulty in releasing water vapor due to high viscosity of the solution. Then the skeleton particles composed of the network of thin film layers were formed. They were decomposed to $r$-alumina keeping this shape. The $r$-alumina consisted of very fine particles. A remarkable grain growth was observed together with transition to $\alpha$-form. The transition initiated from a part of a skeleton particle with a rapid rate. From this fact, the rate controlling process may be the nucleation.

It was confirmed by the electron diffraction that the inside of the skeleton particle showed a high orientation because the transition and grain growth proceeded from one or a few nuclei.

[Received Sept. 3, 1968]

\section{1. まえがき}

活性の大きな粉体の調製法には通常熱分解，あるいは 還元法が用いられる．酸化物粉体の場合には主として塩 の熱分解によって製造しているが，塩の種類によってえ られる粉体の性質たとえば焼結性などは非常に差があ

* 既報のアルミナの焼結に及汸す金属酸化物の影響 (窝協 72 [11-1２04 (1964))，アルミナの表面粒成長に及ぼす金属 酸化物の影響（窯協 74 [3]61 (1966)) をそれぞれアル ミナの焼結に関する研究 (第1 報), (第2 報) として, 本 報をとの（第 3 報）とする。
る、これはできた粉体の形態，粒径㧍よびその分布，格 子欠陥の状態などが異なるためと思われる．これらの差 の生ずる原因としては分解過程における物理的, 化学的 変化，たとえばもとの塩の結晶格子と一定の方位関係を 保ったままの分解，分解過程の途中での中間結晶相の析 出，溶融する場合などがあげられる。

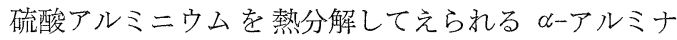
の粒子の形は特殊な形骸粒子であり，それに由来するい ろいろな性質も他のアルミナと異なってくる. 
f $1200^{\circ} \mathrm{C}\left(\alpha-\mathrm{Al}_{2} \mathrm{O}_{3}\right)$

e $1150^{\circ} \mathrm{C}\left(\gamma\right.$ and $\left.\alpha-\mathrm{Al}_{2} \mathrm{O}_{3}\right)$

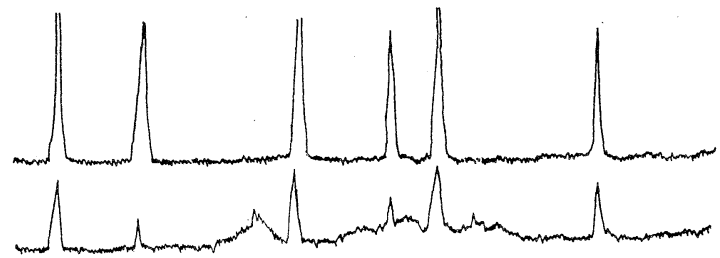

d $1000^{\circ} \mathrm{C}\left(\gamma-\mathrm{Al}_{2} \mathrm{O}_{3}\right)$

c $500^{\circ} \mathrm{C}\left(\mathrm{Al}_{2}\left(\mathrm{SO}_{4}\right)_{3}\right)$

b $200^{\circ} \mathrm{C}$

a as received $\mathrm{Al}_{2}\left(\mathrm{SO}_{4}\right)_{3} \cdot 16 \sim 18 \mathrm{H}_{2} \mathrm{O}$
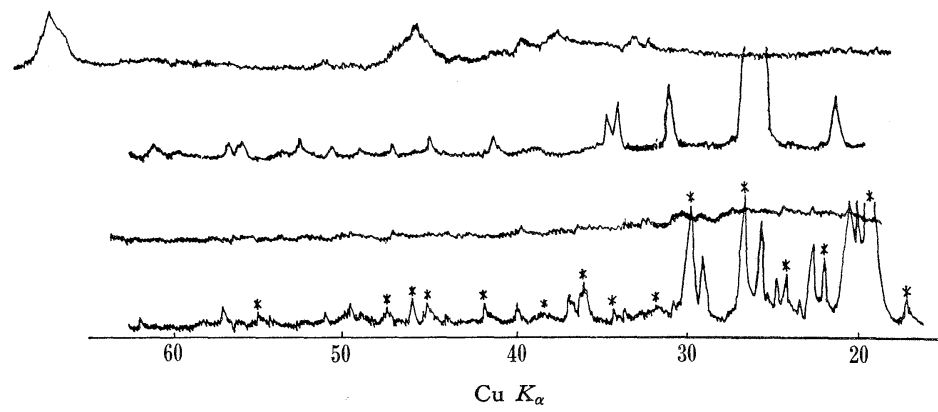

Fig. 1. X-ray diffraction patterns for the materials by thermal decomposition of aluminum sulfate at several temperatures.

われわれは硫酸アルミニウムを分解してえられるアル ミナが他のアルミナよりよい焼結性を示すことを見出し たので，その原因を追求する研究の一環として，まず粉 体の生成過程を調べ，ここに報告する.

\section{2. 実験方法と結果}

\section{1 使用原料}

原料は片山化学製試薬一級硫酸アルミニウムをもちい た．使用原料の X線回折図を図-1 a 亿示寸，*印をつけ た回折線は $\mathrm{Al}_{2}\left(\mathrm{SO}_{4}\right)_{3} \cdot 18 \mathrm{H}_{2} \mathrm{O}$ であるが，残りの線につ いては同定できなかった. ASTM カードには多数の含 水硫酸アルミニウムが記載されているが，該当する化合 物は見出されない，入荷時期の異なる原料についてもX 線回折図に変化は認められなかった。

\section{2 熱天秤，示差熱分析}

含水硫酸アルミニウムは硫酸鉄 ${ }^{11}$ の場合と同様，加熱 によって含有する結晶水に融解し, 一時的に融液状態に なる.このとき融液の粘性は高く, 発生ガス (水蒸気) の離脱が困難であり，そのため脱水を終了した試料は多 孔質の塊状である．この変化のようすを知るために熱天 秤，示差熱分析を用いて追跡した，昇温速度はいずれも， 約 $4^{\circ} \mathrm{C} / \mathrm{min}$ である. 結果を図-2 亿示す. 脱水は二段に 分かれ, 重量減曲線, 示差熱分析曲線とも比較的変化は 少ない. 重量減曲線から第一の脱水は 15 分子に相当し, 第二段の脱水は 3 分子に相当することがわかった。 また 第一の脱水を終了した試料を途中で取り出してみたとこ ろ,すでに多孔質塊状であった。

$885^{\circ} \mathrm{C}$ の吸熱と $1280^{\circ} \mathrm{C}$ の発熱はそれぞれ無水硫酸ア ルミニウムの分解と $r-\alpha$ 転移によるものである.

\section{$2.3 \mathrm{X}$ 線回折}

熱分解過程, 転移過程で生ずる物質の同定を粉末 X線

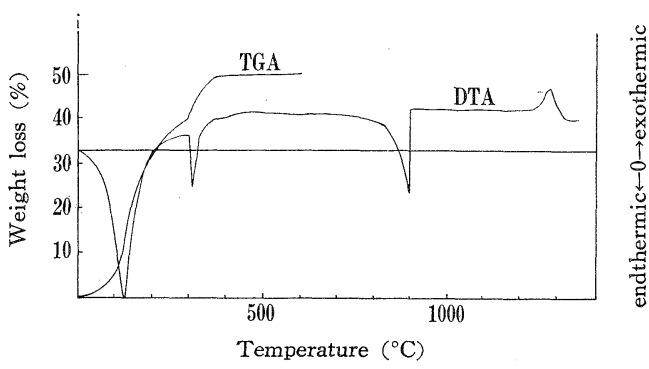

Fig. 2. DTA and TGA curves for aluminum sulfate.

回折法を用いて行なった. 図-1 a 〜 f にその結果を示す. b と c 㵞天秤測定装置によって昇温速度 $4^{\circ} \mathrm{C} / \mathrm{min}$ で 加熱した試料であるが, $1000^{\circ} \mathrm{C}$ 以上で加熱処理した試料 （d～f） は焼結炉による分解，仮焼を経たものである(加 熱速度は $\left.3.3^{\circ} \mathrm{C} / \mathrm{min}\right)$. 第一段の脱水を終了した硫酸了 ルミニウムははっきりした回折線を示さず, 僅かに低角 度に 18 水塩の回折線の痕跡が認めらる程度である（図 $-1 \mathrm{~b})$.

第二段の脱水を終了した試料は無水硫酸了ルミニウム のみの回折線を示す (図-1 c). 無水硫酸アルミニウムは $800^{\circ} \mathrm{C}$ 前後で分解し,$r$-アルミナを生ずる (図 $\left.-1 \mathrm{~d}\right)$. こ の $r$-アルミナはベーマイトを $500^{\circ} \mathrm{C}$ で分解してえられ

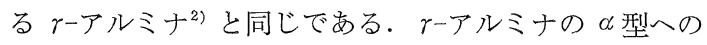
転移は $1100^{\circ} \mathrm{C}$ ぐらいから認妨れ， $1200^{\circ} \mathrm{C}$ 近くまで $\alpha$ 型と $r$ 型が共存する（図-1e)。そして $1200^{\circ} \mathrm{C}$ で完全

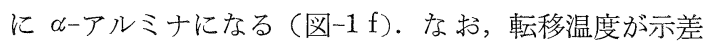
熱分析の結果と異なるのは昇温速度その他の加熱条件が 異なっているためであろう。

\section{4 電子線回折}

形骸粒子内部での配向性をしらべるために $r$ ーアルミ ナと $ム$ アルミナの制限視野電子線回折を行なった. 用 


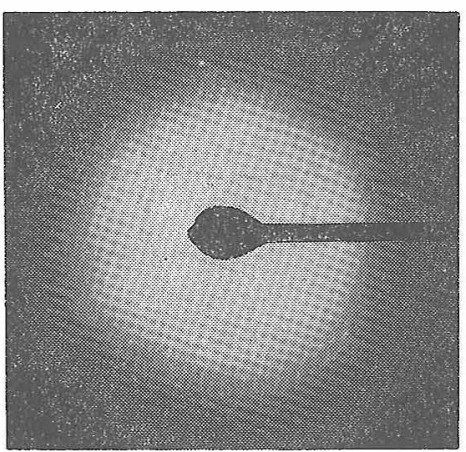

(a)

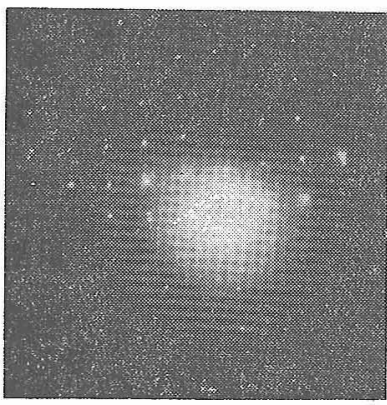

(c)

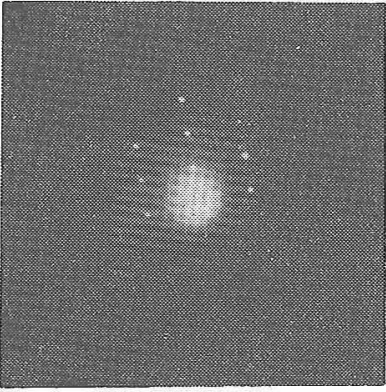

(d)

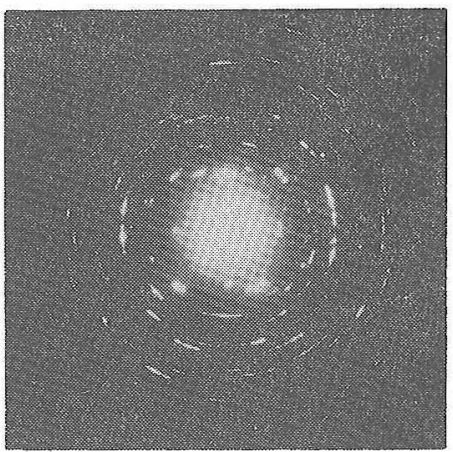

(b)

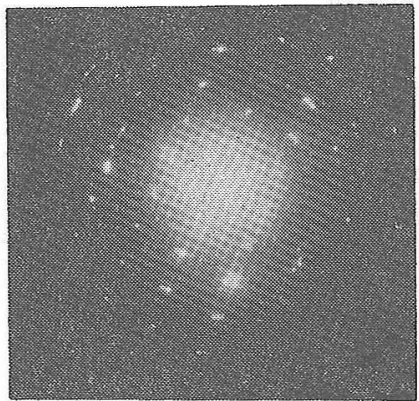

(e)

Fig. 3. Electron diffraction patterns for the $\alpha$ and $\gamma$-alumina by thermal decomposition of aluminum sulfate.

いた電子䫓徴鏡は明石製作所 TRS-50 E 1 である。

試料の大きさは数十么程度の薄膜状であるので電子線 功面に垂直に人射するように，試料を分散させた水滴を あらかしめ用意したコロジオン膜上にのせ，乾懆させた ものを用いた。試料を分散させる際，超音波を用いると 形晍粒子を破壞することがわかったので，試験管を手で 振って分散させるだけにした。

ケーアルミナの回折像は視野をどれだけ絞ってもリング となり，N-パタンは認められない(図-3(a))。

๔ーアルミナの回折像は図-3(b) のように大部分は $N$ パタンの重視したものであるが，中には図-3 (c)，(d) のよらに重複しないパタンも觉られる。視野を絞ること によりきれいな回折像がえられても，視野を拡げるにつ れて乱れてくることもしばしばある(図-3(e)).

粒子の成長方向を知るために $N$-パタンの指数づけを 行なった，力メラ長を補正するために試料に金起蒸着す るとパタンが不明瞭になる、そこで別個に金蒸着膜だけ の回折像をとりそそれからカメラ長を概算した．N-パ タンについてはスポット間の間隔と点列間の角度を測定 し，その両方から最も短い間隔を持つ点列と，その次に 短い間隔を持つ点列の方向をそれぞれ確認した。確認に はステレオ投影図を用いたが，この方法は不必要な計算 の手間が省け，しか子直観的であるので見落しもなく特 殊な場合を除いて既知物質の指数つけには簡便な方法で あると思われる。その結果，大射電子線に平行な晶帯慚
は各試料間で一定せず，粒子の成長方向の間に一定の関 係は見られなかった。約 20 の試料について行なった指 数ゔけの結果をステレオ投影図上に表わしたものを図-4 に揭げる。 $\gamma$ 型とい型の共存する試料についても回折を

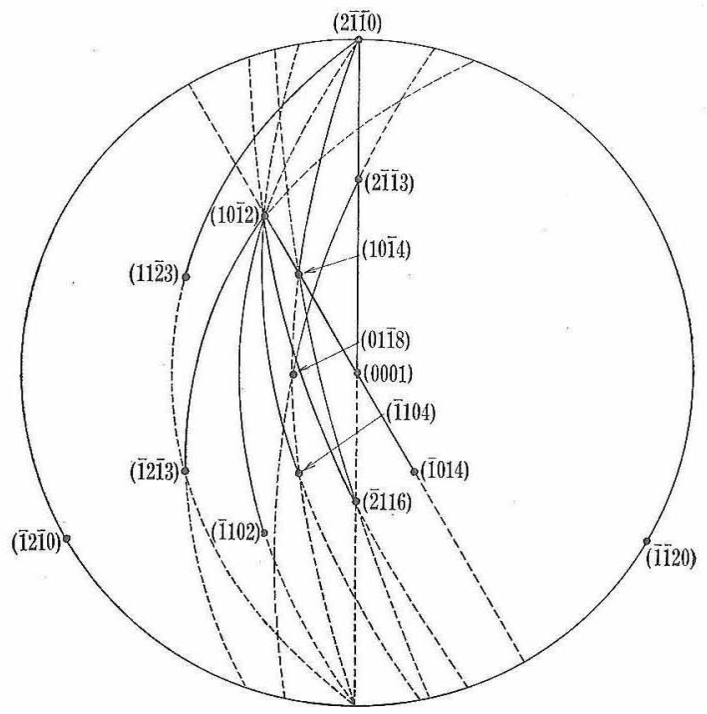

Fig. 4. Combination of indices appeared in electron diffraction pattern for the $\alpha$-alumina by thermal decomposition of aluminum sulfate (Combination of indices drawn by solid line between individual indice appeared as $N$ patterns). 
35 加藤修三ほか

行なったがこれにも特別な結晶方位関係は認められな 加た。

\section{5 電子顕微鏡観察}

前節で述べたよらに超音波を用いて分散させると形骸 粒子が破壞されるので，おもにフリカケ法によって観察 試料を作製した。

アーアルミナは数十 $\AA$ の微細な粒子の集合した薄膜状 形骸粒子であり，中には単一粒子層からできているもの も認められた(図 -5 (a)).

$\gamma-\alpha$ 転移は形骹粒子内の一部から進行し, 急激な内部 粒子の成長を伴なら（図-5(b)). また転移途中にある

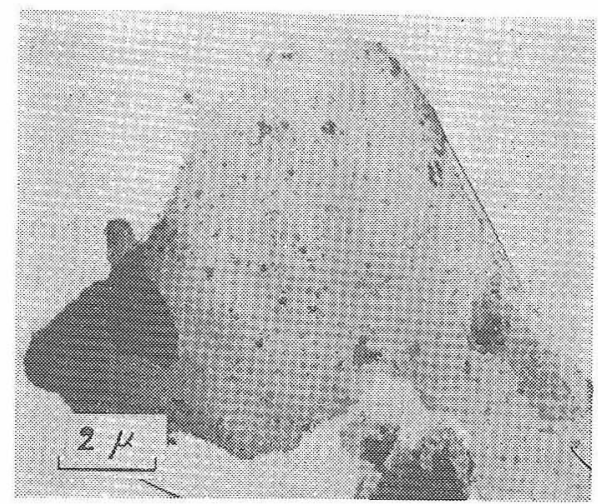

(a)

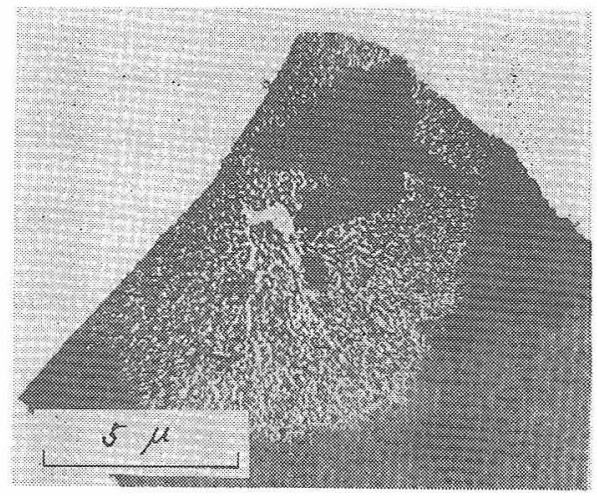

(b)

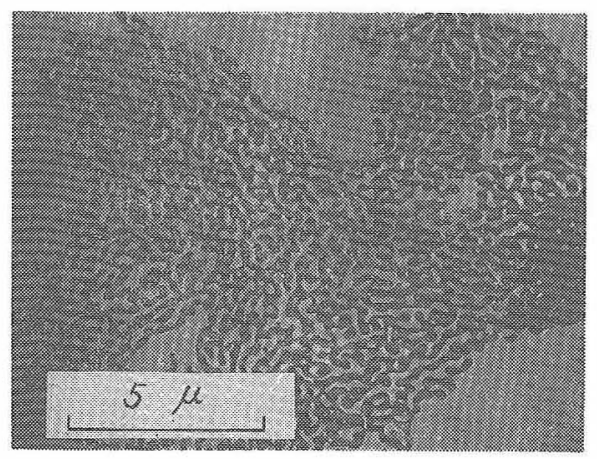

(c)
葖業 協会誌 $77[2] 196963$

粒子も多数観察したが，形骸粒子内部の核の発生は一な いし数ケ程度でほとんど 1 万の核から進行していた。こ れは核生成速度に比較して車移速度の大きいことを意味 している.

ムーアルミナの粒子も形䯓結晶の外形を保ち, 転移後も 変化しない.転移直後の内部粒子の大きさと形注転移前 の形骹粒子の厚さに影響をうける。図-5 (c) は薄いと き，図-5 (d) は厚い場合を示す.

しかしほとんどの粒子が厚み方向には粒子が一重ない し数重の程度の薄膜状形骸粒子であり, 形状もまゆ形粒 子の連結した特徵のある形をしている(図-5 (e), (f)).

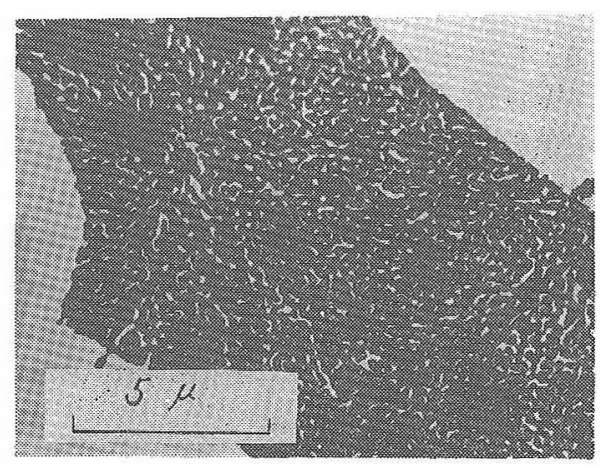

(d)

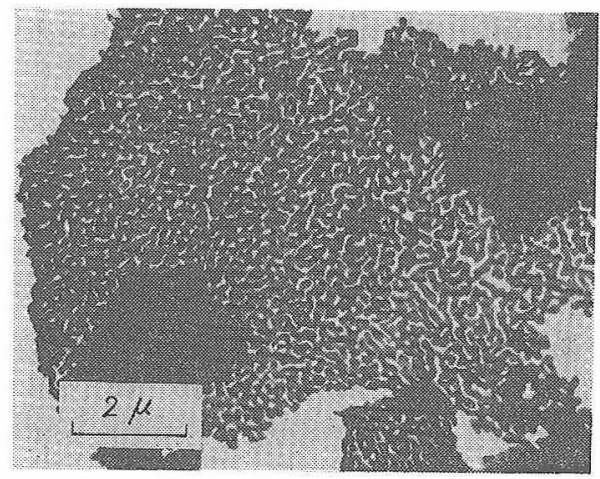

(e)

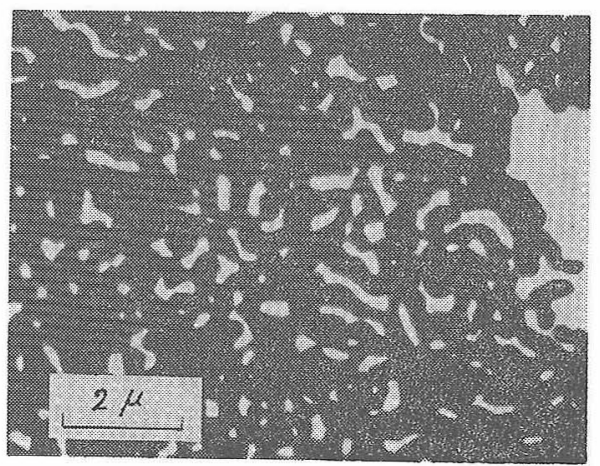

(f)

Fig. 5. Electron microphotographs for the alumina by thermal decomposition of aluminum sulfate at several temperatures. 


\section{3. 考察}

\section{1 熱分解過程}

アルミナ・セラミック用原料としては通常, バイヤー 法アルミナあるいはこれを溶融して作った溶融アルミナ が使用される。これらアルミナは分散させると角ばった 塊状の単一粒子となる。これに対し硫酸アルミニウムを 熱分解してえられた なり，図-5(c)〜(f) に見られるように特殊な薄膜状の 形骹粒子より成る，そこでまずこの形態の生成する過程 について考察することにする.

薄膜状の形䯓粒子は第一段の脱水が終了した時にはす でに生成していることは光学顕微鏡で確認した。した がってこの形骸粒子は第一段の脱水反応の時にできたも のである．その生成の原因としては分解溶融時の液の性 質によると考光られる. 融解した含水硫酸アルミニウム は液の粘性が高く, 発生ガスの脱出が妨害されることを さきに述べた。そのた为多くの泡が発生し，発泡したま まの状態で分解が谁行する. 薄膜状形䯚粒子が生成する のは脱水時の液の粘性が泡を生成し, 泡をつぶさないで 脱水するのに都合のよい状態にあるためと考えられる。

第一段の脱水後の状態がすでに多孔質塊状であるのは そのためである。

ここで生じた形骸粒子の形は ๙ーアルミナにいたるま で変化しない。

また第一段の脱水後のX線回折図（図-1 b) よりこの 脱水物は脱水が不完全で無定形物質 (3 分子の水を含む 硫酸アルミニウムをそのように仮定した場合）と結晶質 （脱水前のもの）の混合物ではないかとの疑いがあるが， この脱水温度 $200^{\circ} \mathrm{C}$ に 約 5 時間保持しても回折図は変 らないのでその可能性は少ないであろう.

無水硫酸アルミニウムは $800^{\circ} \mathrm{C}$ 前後で分解し, $r$-ア ルミナを生ずるが，この反応は非常に遅い。ここでは詳 しく調べなかったが

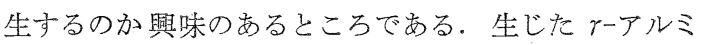
ナはそれぞれもとの形骸粒子に応じて厚みが変り，それ が転移後の๙ーアルミナにまで影響する。また ナの単一粒子層の厚み流数十 §であるが，生じたばか りの薄膜状粒子あるいは無水硫酸アルミニウムの粒子の 厚みよりも分解して除去された物質の分だけ薄くなって いると考えられる．生じた $r$ アルミナの内部粒子は非 常に微細であるが，加熱により転移までに僅かに粒成長 する。

\section{2 転移過程}

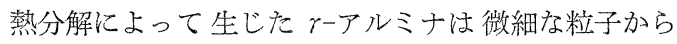
なる形骹粒子であるが転移により著しい粒成長を示す。

示差熱分析によれば約 $1280^{\circ} \mathrm{C}$ で する。しかし真温速度 $3.3^{\circ} \mathrm{C} / \mathrm{min}$ で $1200^{\circ} \mathrm{C}$ まで炍焼 したものは注完全に $。$ 化していることがX線回折で確
かめられる (図-1 f)。この差は昇温速度の違いによる ものであろう。電顕観察によれば転移したブロックと転 移しないブロックとは形骸粒子が単位となっている。そ のことと転移が形䯏粒子の一部から進行していることと から核生成速度が転移を律速していると考它られる。い ったん転移した核が発生すると転移が早く進行するが， これは内部粒子の成長を伴なら転移であるためである

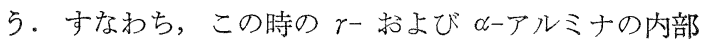
粒子の粒径の差は大きく，これが結晶化学的自由エネル ギーの差のほか汇表面エネルギーの大きな差をもたら し, 内部粒子の成長（この場合には転移を意味する）に 寄与すると考えられる.

図-5 の写真に見られるような形骹粒子の形態怔金属 粉の還元生成の際に観察されているが，その生成の理由 として, 分解して生じた粒子が再び焼結してまゆ型連結 状になると考えられている。しかしこのアルミナの場 合，いわゆる焼結ではなく転移時の内部粒子の成長に よってこのような形態が生じたことは明らかである。ま た1ないし数ケの核から転移が進行していることから， 結晶方位に高い配向性が期待される。生じたばかりの ム-アルミナの電子回折像はスポットがきちんと整列し ていないのが多く, 単結晶あるいは双晶といら可能性は 小さいが，部分的な狭い範囲の回折像はきちんと整列し たスポットがあらわれており，高い配向性を持っている ことが認められる。個々の形骸粒子の成長方向が特定の 結晶方位でないのは成長方向の決定が薄膜粒子の方向と 最初に発生した転移した核の結晶方位との関係にのみに 支配されるためであろう。

なお，その後の加熱処理による変化については内部粒 子の成長のため電子線が容易に透過せず回折像をらるの が困難であったので調べていないが，大きな変化はない と思われる。

\section{4. 総括}

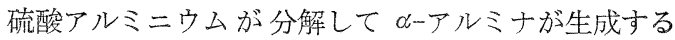
過程を熱天秤, 示差熱分析, X線抢よび電子顕微鏡を用 いて追跡した. その結果, つぎの過程を経て $\alpha$ アルミ ナが生成することが明らかとなった。

硫酸アルミニウムは加熱していくとまず自己の結晶水 に溶解し, 粘性の高い液となる. $100^{\circ} \mathrm{C}$ 前後から水蒸気 の発生が盛んとなるが高粘性のために離脱が困難で発泡 体の様相を示すようになる。このとき形成された形骹粒 子が $\alpha$ アルミナ生成まで継続する. 生成した形骹粒子 は発泡体に特有の薄膜状である.この形状のまま脱水

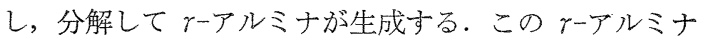
は径約数十 の微細な内部粒子から成っているが，転 移とともに著しい粒成長を示す， 型への転移は形骸粒 子の一部から進み，その速度は大きい。このことから核 
生成が転移の律速となっているものと考元られる，電子 線回折により形骸粒子内の内部では高、配向性が認めら れたが，これは 1 数個の核から転移，粒成長するため と思われる。転移したアルミナの粒子はまゆ型連結性の 形骸粒子である.この形態は続報で考察する予定である が，焼結性のよいことと関係があるものと考えられる。
学斎藤教授, ならどに研究を行なうに当り御鞭撻を賜った名古 屋工業技術試験所第 5 部奥田課長に深甚なる謝意学表します。

\section{文献}

1）久保輝一郎, 谷口雅男, 白崎信一, 工化誌 64 [2] 256261 (1961).

2) R. Tertian and D. Papée, Journal de Chimie Physique et de Physicochimie Biologique 55, 341-53 (1958).

(9/3/1968 受付)

\title{
融剤法による Rutile $\left(\mathbf{T i O}_{2}\right)$ 単結晶の育成
}

\author{
菅 井德行・長谷川修三 \\ (東北大学電気通信研究所)
}

\section{Crystal Growth of Rutile $\left(\mathrm{TiO}_{2}\right)$ by Flux Method}

\author{
By \\ Tokukō SUGAI and Shuzo HASEGAWA \\ (Research Institute of Electrical Communication, Tohoku University, Sendai)
}

\begin{abstract}
Single crystals of rutile $\left(\mathrm{TiO}_{2}\right)$ were grown from several fluxes. The good results were obtained with $\mathrm{Li}_{2} \mathrm{O}-\mathrm{MoO}_{3}$ flux systems. Using $\mathrm{Li}_{2} \mathrm{O}-m \mathrm{MoO}_{3}$ fluxes, the habit and color of growing crystals vary with the amount of $\mathrm{MoO}_{3}$, which bring with it single crystals comparatively large in size. They vary continuously in form and color, from needle-like transparent crystal to prism-like and short-prism-like, black or opaque crystals.

The growth experiments were carried out by slow-cooling method, temperature of growth being $1250^{\circ} \mathrm{C}$ to $800^{\circ} \mathrm{C}$ and cooling rate with $7^{\circ} \mathrm{C} / \mathrm{hr}$. The grown crystals obtained in such a method have needle-like habit 15 to $20 \mathrm{~mm}$ in length elongated to $c$-axis and prism-like $1.5 \mathrm{~mm}$ in diameter and $10 \mathrm{~mm}$ in length, both being comparatively large in size and transparent free from inclusions.

The solubility of rutile was measured from $1000^{\circ}$ to $1300^{\circ} \mathrm{C}$ in $\mathrm{Li}_{2} \mathrm{O}-2 \mathrm{MoO}_{3}$ solvent, and also flux composition was varied from $m=1$ to $m=3$ at constant temperature $1150^{\circ} \mathrm{C}$. The solubility was found to slightly increased dependent on $\mathrm{MoO}_{3}$ content. The dependence on temperature was found to almost linearly increased ranging from $1200^{\circ}$ to $1300^{\circ} \mathrm{C}$.
\end{abstract}

[Received Sept. 9, 1968]

\section{1. 緒言}

ルチル $\left(\mathrm{TiO}_{2}\right.$, 金紅石 $)$ は元来高誘電物質として評価 されてきたものであるが，近年における固体物理学の発 展にともない, その物性が幅広く調べられるにいたっ た. 特に電気的, 光学的性質の特異性等から, 最近注数 多くの破究者の注目をあつめている物質であるが ${ }^{114)}$ その単結晶の育成は Flame Fusion 法 (Verneuil method) によってなされているにすぎない。この方法では かなりの大きさを持つボウル (boule) が短時閶に得ら れる利点をもつ一方, 所要の方位, 品質の単結晶が得難 い. 最近では Flame Fusion 法によらない育成法につ いて種々な試みがなされるようになった。
溶融点が比較的高いこと，高温で還元され易いことな どから Berkes ら ${ }^{57}$, および Anikin ら ${ }^{6}$ は $\mathrm{Na}_{2} \mathrm{O}\left(\mathrm{K}_{2} \mathrm{O}\right)$ $\mathrm{B}_{2} \mathrm{O}_{3}$ 系のいわ的硼砂 (Borax) 用いた融剤法による 育成を行ない, また Anikin らは気相法, 水熱法による 育成を試多た。

一般に溶融塩からの育成法は所要の晶癖, および方位 をもつ自形の単結晶を得る手段として有効, かつ比較的 簡便な方法であるが，Borax 系を融剤に用いた Berkes， Anikin らの得た結晶はいずれも $c$ 軸方向に極端に長い 針状晶で, しかも $c$ 軸方向の長さが最大 $3 \sim 4 \mathrm{~mm}$ 程度 の小さな結晶にすぎない，融剤法で育成したルチルは一 般に $c$ 軸方向への成長速度が大きく, ほとんぞの場合針 